\title{
Ocorrência de Cisticercose, Tuberculose e Hidatidose em Bovinos Abatidos Sob Inspeção Estadual no Rio Grande do Sul, Brasil, em 2013.
}

\section{Roque Fernando Bica (I), Mário Celso Sperotto Brum (I), Marina} Venturini Copetti (II,I)

(I) Unipampa - Universidade Federal do Pampa (PPGCA, Uruguaiana-RS, Brasil), (II) UFSM Universidade Federal de Santa Maria (Av Roraima 1000, CCR/DTCA, Prédio 42, sala 3210.

CEP 97104-900, Santa Maria-RS)

\section{Resumo}

A carne bovina é um alimento bastante presente na dieta da população brasileira, com um consumo per capita anual estimado em $40 \mathrm{Kg}$. O estado do Rio Grande do Sul possui uma pecuária forte com um rebanho de aproximadamente 14 milhões de bovinos, os quais estão distribuídos em 496 municípios. É de conhecimento que a carne é um alimento com potencial para transmissão de zoonoses se não passar por um adequado controle higiênico-sanitário no momento do abate e for consumida crua ou mal passada. Além disso, animais contaminados mantêm agentes de enfermidades no ambiente, favorecendo a continuidade dos ciclos infecciosos e colocando em risco a saúde humana. O objetivo deste trabalho foi realizar um estudo epidemiológico sobre a ocorrência de cisticercose, hidatidose e tuberculose em animais abatidos em frigoríficos sob inspeção sanitária do CISPOA (Coordenadoria de Inspeção de Produtos de Origem Animal) do estado do Rio Grande do Sul no ano de 2013. Os dados foram obtidos através de consulta ao banco de dados da Secretaria da Agricultura Pecuária e Agronegócio (SEAPA) do estado. O estudo analisou a frequência das lesões encontradas e o município de origem das carcaças, reunidos por microrregiões. Um total de 390.341 bovinos foram abatidos sob inspeção do CISPOA no período em questão. A cisticercose teve uma ocorrência média de $2,38 \%$ e as microrregiões com maior prevalência foram as regionais de São Luiz Gonzaga com 6,28\%, Santa Rosa com 4,9\%

\footnotetext{
Referência:

Roque Fernando Bica, Mário Celso Sperotto Brum, Marina Venturini Copetti. Ocorrência de Cisticercose, Tuberculose e Hidatidose em Bovinos Abatidos Sob Inspeção Estadual no Rio Grande do Sul, Brasil, em 2013.. In: Anais do 12을 Congresso Latinoamericano de Microbiologia e Higiene de Alimentos - MICROAL 2014 [= Blucher Food Science Proceedings, num.1, vol.1]. São Paulo: Editora Blucher, 2014. DOI 10.5151/foodsci-microal-247
} 
e Erechim com 4,17\%, e as com a menor frequência foram de Alegrete, Bagé e Estrela, com valores inferiores a 1\%. Com relação à tuberculose, os resultados das regiões foram semelhantes ao da média do estado com um índice de 0,73\%; com exceção da região de Passo Fundo onde o índice foi $7,35 \%, 10$ vezes superior à média estadual. A hidatidose apresentou a maior ocorrência dentre as zoonoses avaladas, com uma média de 8,64\%, com destaque para as regionais de Bagé com 20,14\% e Pelotas com 20,26\%. Embora o conhecimento de dados de ocorrência seja de grande relevância para a elaboração de planos de prevenção e erradicação de enfermidades com caráter zoonótico, estudos epidemiológicos envolvendo doenças zoonóticas de transmissão por alimentos ainda são escassos. Maior atenção deve ser dada a este tópico, tanto em virtude do perigo que representam à saúde pública quanto às perdas econômicas decorrentes do descarte de carcaças abatidas.

Palavras-Chave: Zoonose, Tênia, Inspeção sanitária, Epidemiologia, DTA Agência de Fomento: 